\title{
The Influence of Implementing Communicative Approach in the Language Teaching Process on Students' Academic Achievement
}

\author{
Bambang Budi Wiyono \\ Faculty of Education, Universitas Negeri Malang, Malang, East Java, Indonesia \\ Muhana Gipayana \\ Faculty of Education, Universitas Negeri Malang, Malang, East Java, Indonesia \\ Ruminiati \\ Faculty of Education, Universitas Negeri Malang, Malang, East Java, Indonesia
}

\begin{abstract}
This research is aimed at determining the effect of implementing communicative approach in language teaching on the students' learning outcomes. The research was conducted in Blitar, East Java, Indonesia. The research employed descriptive correlation design and 40 elementary school teachers were selected as samples by random sampling technique. Data collection technique used questionnaires and documentation, and the analysis technique employed descriptive statistics and Pearson Product Moment correlation. The results indicated that implementing communicative approach in the language teaching did not significantly influence the students' learning outcomes in the national examination. If it was seen from the items of activities which had been performed in the learning process through communicative approach, there were some items that have significant influence towards students' learning outcomes in social science.
\end{abstract}

Index Terms - communicative approach, language teaching and learning, students' academic achievement, national examination

\section{INTRODUCTION}

Education is the primary means to educate the nation. Along with the rapid development of science and technology, it also increases the function of education in the life of the nation. Education is not only a destination, but it is the main asset for the success of the national development. Therefore, in order to fulfill its function, the quality of education needs to be constantly improved.

The core activities that improve the quality of education essentially enhances students' achievement. The main goal of improving the quality of education is to improve the quality of students' learning outcomes. Students' learning outcomes are the reflection of knowledge, skills and attitudes obtained by students in following the teaching and learning process. Hence, they are showed by the students' achievements. Thus, the efforts to improve the quality of education is essential to increase the students' achievements.

Students' achievements are influenced by both internal and external factors. One of the factors that is very influential on the students' achievements is the quality of teaching performed by teachers. The quality of teaching performed by a good teacher can bring improvement of a good climate in the teaching and learning process. Through the good climate of teaching and learning process, a good learning performance will be obtained. In addition, there is a positive effect of the teachers' work motivation on the school improvement (Wiyono, 2017, p. 11).

Teaching language is one of the very important areas of teaching in schools. In addition, it has special characteristics which requires a specific approach in its implementation. To produce good students' achievements, the language teaching should be performed by the right approach. Learning activities refer to the technique, method or strategy selected to achieve the goal of teaching.

Moreover, teaching language is presented in three components, namely linguistic, comprehension and utilization. Linguistic component includes pronunciation, spelling, punctuation, structure, vocabulary, paragraphs, and discourse. The teaching of literature is integrated in the language teaching. Whereas pronunciation refers to accurate and clear pronunciation; and proper intonation in an appropriated language situation. Spelling and punctuation are taught to familiarize students to read and write with high degree of accuracy. While vocabulary, structure, paragraphs and discourse are emphasized on the comprehension activities and used to the right context and directed at the development of ideas.

Comprehension and utilization component refer to the implementation of language teaching. Comprehension includes listening and reading skills. This learning process includes developing the ability to absorb ideas, opinions, 
experience, messages, and feelings that are spoken or written. While the utilization refers to the teaching, the aim is to make students can communicate, both spoken and written. The teaching objectives can be achieved through the teaching of writing and speaking, which includes the development of ability of exploring ideas, opinions, experience, messages, and feelings.

Language teaching techniques emphasize on the function of language as a communication tool. Teaching methods are selected according to the purpose of language and the circumstances of the students. To avoid saturation, it is suggested to use a variety of methods. The learning process performed inside or outside classroom uses various tasks, for instance individuals, pairs, groups or involving the entire students in the class. The evaluation system of language teaching is emphasized on the evaluation process and learning outcomes. The objectives of the evaluation include knowledge, skills and the attitude of speaking. The implication is executed by evaluating the activities and progress of learning in the form of assessments, provision of advice, additions, and improvement during and after teaching activities. The implications of teaching Indonesian that can meet the needs in terms of materials, methods or evaluation system, needs to be performed through a good teaching approach. One approach applied is called communicative approach.

\section{LITERATURE REVIEW}

Communicative approach is an approach that emphasizes on the use of language as a communication tool. In this approach, language is seen as something dealing with what to do (function) or meaning which can be expressed through the language. In other words, communicative approach refers to the nature of language that has a function of communication not only knowledge but also structure and vocabulary.

In the implementation of communicative language teaching approach, there are four competencies including grammatical, sociolinguistic, discourse, and strategic competence. It is in accordance with Abate (2014) who suggested that there were four elements of communicative competence, i.e grammatical, discourse, pragmatic, and strategic competence. Grammatical competence is linguistic competence, which includes a mastery of language cues, an ability to recognize and use of the characteristics of vocabulary, morphology, syntax, and phonology, school of words and sentence formation. Sociolinguistic competence is interdisciplinary competence. People can use language properly, fairly and suitable for the social context of language usage. Discourse competence is related to the interpretation of discourse or language structures that is larger than topic sentences, paragraphs, chapters, books or appreciation of literary works. While the strategic competence is the ability to use language along with several strategies to avoid insufficiency of language knowledge of the speaker.

There are eight basic principles of the communicative approach, namely: (1) teaching of language was emphasized on language as a means of communication, (2) diversification was acknowledged and accepted as a part of language development, (3) students' competency was relative, (4) language variation was recognized as a model that was run continuously, (5) culture was recognized as an instrument that formed communicative competence, (6) there was no single method defined, (7) the use of language was recognized as an ideal service, which had textual and international functions, and ( 8) students loved the language that was used for various purposes (Abade, 2014, p.129). Teachers need to understand the principles well in application of the communicative approach at the classroom situation. The usage level of the communicative approach is depended on the degree of application of these principles in classroom situation.

Communicative approach emphasizes on communication in the learning process rather than mastery of linguistic forms. Teacher's role is to facilitate students in the communication process. While the students do a lot of practice. In addition to that, accuracy and fluency are used simultaneously. Jin (2008) showed that students developed communication while practicing the language competence. Thus, the communicative approach in language teaching is aimed at establishing communication competencies, not merely shaping linguistic competence. Students were guided not only to be able to use the language in various contexts of communication but also to know about the language (Sehe, Tolla, Kamaruddin, Hamsa, 2016, p. 914).

Communicative language teaching approach is to develop students' communication competencies which include the ability of interpreting linguistic forms which is explicitly or implicitly stated. Sekiziyivu and Mugimu (2016) said that communicative approach assumed two purposes, namely learning the language to learn it and to use it. Goal achievement is eventually to improve students' learning outcomes in Indonesian, but so far, it has not been studied carefully how different teaching Indonesian by implementing communicative approach to the improvement of students' achievements is.

The fact in the field is considered that language teaching has not been conducted well. The study results of Asmari (2015) in Saudi Arabia revealed that teachers were confronted by various challenges related to teachers, students, education system, and communicative language teaching. Some problems were lack of communicative language training, accessing communicative language teaching, low-proficiency, lack of motivation among students, evaluation system to assess communicative competence of students. In addition, the communicative approach has not been performed utterly in Indonesian. The research results from Nurchasanah (1995, p. 48) suggested that learning Indonesian was still grammatical oriented. Some teachers claim that they use communicative approach, but their materials and techniques have not shown it.

When it is examined further, based on the Law No. 2 on National Education System, Indonesian language teaching in elementary schools does not solely make the literate output, but it should be provided with foundation to establish 
various abilities that determines the next success. The purposes of teaching Indonesian at schools are to: (1) install basic knowledge of Indonesian language, (2) encourage the possession, love, and pride to be Indonesian, and (3) establish students' language skills. Therefore, This research was conducted based on this idea.

The purpose of this research is to find out the influence of Indonesian language teaching by implementing communicative approach towards students' achievements. As the target, this research was conducted in elementary schools since it is considered that elementary school is the first fragment of nine-year study launched by the government. When Indonesian subject is controlled well at the elementary school level, it will support the Indonesian language to be better on further education levels.

This research focuses on the main issues that Indonesian language teaching through communicative approach is limited to some aspects, they are: (1) the determination of educational objectives, (2) the determination of teaching materials, (3) the use of teaching methods, (4) the use of learning resources or teaching media, the use of teaching and learning strategies, and (5) the evaluation of Indonesian language teaching through communicative approach. While the students' achievement is limited to academic achievement of subjects that are examined nationally, namely Mathematics, Natural Science, Indonesian Language and Social Science, as indicated by the value of learning outcomes achieved by the students in the subjects.

\section{RESEARCH METHOD}

The purpose of this research is to examine the influence of implementing communicative approach in teaching on the students' learning outcomes in Indonesian subject. This research employed descriptive correlational design. Forty teachers of elementary schools in Blitar, East Java, Indonesia, were selected as samples of the research.

The technique of data collection employed questionnaires and documentation. These research instruments were developed based on research variables construct and validated by expert. Before it was applied, tests were executed to see the reliability and validity of the instruments. Based on the results of the analysis of experimental data, it could be underlined that the instruments showed good validity with each item coefficient $>0.3$, and the estimation of reliability was also good, with reliability coefficient of Alpha Cronbach > 0.7 .

The communicative approach in Indonesian language teaching was observed from principles in teaching and learning activities. The implementation of the principles included making real communication as the focus of learning, providing opportunities for learners to do various experiment related to mastered competencies, and connecting various language skills. Learning activities focused on two aspects, namely fluency and accuracy. Furthermore, in the process of learning, there were a lot of teaching methods that concerned with interaction, such as role playing, discussion, simulation, or dialogue practice. Academic achievement of students was seen from five components, they are the grades of national examination results for Mathematics, Natural Science, Indonesian Language, and Social Science, as well as the average grade.

The Data were analyzed using two analytical techniques, namely descriptive statistics and correlation analysis of Pearson Product Moment. Descriptive statistics was used to describe the process of learning and implementing communicative approach that performed by the teachers. Statistical correlation was also used to examine the relationship between the implementation of communicative approach performed by the teachers and the students' achievements. Then, the classification of the grades determined by using the formula of descriptive analysis, uses the range divided by the number of classes. Based on this formula, the grades classification of implementing communicative approach in learning process is defined as presented in Table 1.

TABLE 1

THE GRADES ClassifiCATION OF IMPLEMENTING COMMUNICATIVE APPROACH IN TEACHING AND LEARNING PROCESS

\begin{tabular}{|l|l|l|}
\hline No & Score Interval & Criteria \\
\hline 1 & $36-65$ & Very less \\
\hline 2 & $66-94$ & Less \\
\hline 3 & $95-123$ & Adequate \\
\hline 4 & $124-152$ & Good \\
\hline 5 & $153-180$ & Very good \\
\hline
\end{tabular}

\section{RESUlts}

The purpose of this research is to test the effectiveness of implementing communicative approach in Indonesian language teaching to improve students' achievements in Indonesian, Mathematics, Natural Science and Social Science. The description of the research results about the level of implementing communicative approach in learning Indonesian is presented in Table 2 . 
TABLE 2

IMPLEMENTATION OF COMMUNICATIVE APPROACH IN TEACHING PROCESS OF INDONESIAN LANGUAGE

\begin{tabular}{|l|l|l|l|}
\hline Score Interval & $\mathrm{F}$ & $\%$ & Criteria \\
\hline $95-123$ & 5 & $12,5 \%$ & Adequate \\
\hline $124-152$ & 33 & $82,5 \%$ & Good \\
\hline $153-180$ & 2 & $5 \%$ & Very good \\
\hline
\end{tabular}

Based on Table 2, it shows that most of the teachers have been implementing communicative approach to the teaching and learning process. These results were collaborated by mean values obtained in this research, that is 133.4. This average is categorized as goog. Thus, we can conclude that teachers based on the average, have been implementing communicative approach in learning Indonesian.

Furthermore, the influence of implementing communicative approach in learning Indonesian towards students' achievements is analyzed by using Pearson Product Moment correlation analysis. Generally, the result of correlation analysis is presented in Table 3.

TABLE 3

CORRELATION ANALYSIS RESULTS OF THE IMPLEMENTATION OF COMMUNICATIVE APPROACH IN TEACHING AND STUDENTS’ ACADEMIC ACHIEVEMENTS

\begin{tabular}{|l|l|l|l|l|l|}
\hline Variable & Mathematics & Natural Science & Indonesian & Social Science & Average \\
\hline $\mathrm{r}$ & 0,076 & 0,124 & 0,157 & 0,159 & 0,062 \\
\hline $\mathrm{p}$ & $\mathrm{p}>0,05$ & $\mathrm{p}>0,05$ & $\mathrm{p}>0,05$ & $\mathrm{p}>0,05$ & $\mathrm{p}>0,05$ \\
\hline
\end{tabular}

Table 3 above demonstrates that there is no evidence of a significant positive relationship between the implementation of communicative approach in Indonesian language teaching process and the students' achievement. The highest correlation value among four subjecs was Social Science. These results were supported by the results of each analysis item of the instrument. There were significant positive correlation coefficient between the indicator items of implementation of communicative approach and the students' achievements, especially the grades of Social Science. Sample results of the correlation analysis are presented in Table 4 below.

TABLE 4

CORRELATION ANALYSIS RESULTS OF THE COMMUNICATIVE APPROACH ITEMS IN TEACHING AND STUDENTS' ACADEMIC ACHIEVEMENTS

\begin{tabular}{|l|l|l|l|}
\hline No & Statements of Item Instrument & $\mathrm{R}$ & $\mathrm{p}$ \\
\hline 1 & Tolerate the mistakes made in the learning process & $0,359^{*}$ & $\mathrm{p}<0,05$ \\
\hline 2 & Practice the language without context to the students & $0,335^{*}$ & $\mathrm{p}<0,05$ \\
\hline 3 & No need of meaningful communication in the learning process & $0,389^{*}$ & $\mathrm{p}<0,05$ \\
\hline 4 & Using the method of experience review in the learning process & $0,451^{*}$ & $\mathrm{p}<0,05$ \\
\hline
\end{tabular}

On Table 4, it can be seen that there are some items of activities as part of the implementation of communicative approach that have significant positive relationship with students' achievements, particularly for Social Science. From those four items, there was a reference to the principle activities that emphasized on fluency, and there was a reference to the principle that emphasized on accuracy.

\section{DISCUSSION}

Based on the results of data analysis, it can be concluded that teaching and learning proses using communicative approach do not significantly influence students' academic achievements, particularly the national examination results. However, when it is observed from the components of communicative approach, there are some things showing significant positive correlation. When it is seen from the correlation value, the highest correlation coefficient is the result of Social Science, then Indonesian Language, followed by Natural Science, and the last was Mathematics tests.

The results of this study then indicated that there was no relationship between the implementation of communicative approach upon the students' achievements comprehensively. Academic achievements were taken from the results of the national exams. When it is explored further, the national examination is mainly concerned with cognitive aspects and the type of questions used is only multiple choice, whereas communicative approach emphasizes the use of language in practice in our daily life. It is suspected as a cause of the absence of significant positive relationship between the implementation of communicative approach towards the students' achievements. Furthermore, it was related to the research results conducted by Wiyono and Sutopo (2015) which showed that psychological values and English language of the students could not become a strong prediction towards the index performance of graduated students.

There were some other studies done by previous researchers that support the result of this study. Firstly, the research done by Ahmad et al (2014) who found out that communicative approach had a strong positive influence on the students' speaking ability. There are significant differences on the students' speaking ability who has been taught by communicative approach combined with other methods on all components, fosr instance content, fluency, delivery, and language accuracy. However, the results merely emphasize the influence of communicative approach to the students' speaking ability but it does not give any effects on the cognitive abilities. It was also in line with the study results by 
Chen, Jiang and $\mathrm{Mu}$ (2015) that indicated that introversion/extroversion was not a key factor contributing to the success of spoken English learning. Therefore, the teaching and learning strategy using communicative approach is the effective method to improve students' speaking ability.

Secondly, the results were also in line with the research conducted by Agbatogun (2014) who asserted that there was a strong influence of communicative approach to students' communicative abilities. It was shown that students' communicative abilities were significantly improved after being taught using communicative approach than traditional approach. Correspondingly, it was supported by the results of Elmaksoud's research (2013) which showed that there was an increased ability of students taught using communicative approach in several sub skills.

Thirdly, the results of this study were also supported by the study of Caganaga (2014) which mentioned that there were differences in students' abilities in English who were taught using communicative approach and traditional approach, particularly in the areas of speech. Students' perception on learning is also very good. The level of students mastery of the language increases based on the approach and applied learning program.

Next, Chang's research (2011) also admitted that teachers had a positive attitude towards the principles of language learning using communicative approach. Teachers believe that learning a language using communicative approach is effective and meaningful. Furthermore, it was also in accordance with the research conducted by Jing and Minghe (2015) which found that the application of communicative approach had a positive influence on the ability of students' oral communication competence and improvement of students' communication competence.

Then, Mesgarshahr \& Abdollah (2014) found out that the level of students' willingness of communication who were taught using communicative approach was higher than students taught by traditional approach. As a result, learning by communicative strategies can facilitate and encourage students' motivation to communicate well in the classroom.

The results of Kasumi's research (2015) showed that the students' language learning outcomes were developed especially in listening and speaking than the traditional approach, while writing was relatively low. It was also supported by Ahmed and Rao's (2013) study who found out that there were significant differences in learning outcomes of students who were taught using communicative approach and students taught by traditional approach, particularly in the areas of idioms, general and contextual speaking, while in the comprehensive materials, vocabulary, and essay did not show significant difference.

In the same way, Jafari and Rad (2016) in their research initiated that phonological and grammatical awareness had significant role in reading performance of English as a foreign language. In other words, there is significant correlation between phonological and grammatical awareness, sentence and word reading. This result was also supported with the study results of Harkio and Pietila (2016) which indicated that vocabulary breadth and depth were the strong predictors of reading comprehension skills in lower levels of proficiency.

Finally, the results of this research were also supported by Basta (2011) who found out that collaborative learning helped students to acquire life skills, academic skills, and social skills. Related to the communicative approach, collaborative learning emphasizes the students' interaction in the learning process. It was in line with Shahneaz, et al. (2013) who argued that communication skills could be improved through club or language groups, debates, or other interaction techniques which could motivate students in learning environment that could enhance students' communication.

To summarise, it can be concluded that communicative approach can improve the communication skills of the students. Students' communication competence can be developed by providing a lot of opportunities for students to practice communication in the learning process. If it is observed using the components of language learning, not all components can optimally be increased. Sub competencies which are effectively improved are oral communication and social competence, like speaking and listening, while writing competence is not significantly increased, such as reading comprehension, vocabulary, and writing. Therefore, language learning by implementing communicative approach does not contribute a lot to the score of national examination which tends to emphasize on the use of knowledge, not the practice.

\section{CONCLUSION}

Based on the research findings, it can be concluded that the use of communicative approach in Indonesian language teaching did not have a significant effect on students' academic performance in national examination. The national examination emphasizes on measuring students' knowledge aspects. Therefore, the communicative approach in Indonesian language teaching does not have a strong influence on the language knowledge.

When the research findings were seen from items of the communicative approach characteristics, there were some items that showed significant positive correlations, particularly with the national examination results of Indonesian Language and Social Science. This study proves that the use of communicative approach in language teaching has significant positive effect on the students' ability of language practices. Moreover, it also has significant positive effect on the social skills of the students.

Furthermore, teachers can use the communicative approach in language teaching to improve students' competence in communication practices. In addition, through the use of communicative approach, teachers can improve students' social skills. Whereas, it is essential to use other relevant teaching strategies to increase the mastery of language knowledge of students. To obtain a more comprehensive conclusion, further research needs to be done with the 
experimental method. Finally, the effect of the communicative approach components in language teaching on each subject need to be studied comprehensively.

\section{REFERENCES}

[1] Abate, E.B. (2014) Prospects and challenges of communivative approach in EFL context, Research on Humanistic and Social Sciences, 4 (25), 128-136.

[2] Agbatogun, A.O. (2014). Developing learners' second language communicative through active learning: Clickers or communicative approach?. Educational Technology \& Society, 17 (2), 257-269.

[3] Ahmad, N.M., Mansor, N., Ibrahim, S.H., Salam, W.N.W., Mamat, M.Z., \& Nordin, N.I.J. The impact of communicative approach on students'speaking skills. Journal of Business and Social Development, 2 (1): 63-67.

[4] Ahmad, S., \& Rao, C. (2013). Applying communicative approach in teaching english as foreign language: A case study of Pakistan. Porta Linguarum, 20, 187-203.

[5] Asmari, A.R.A. (2015). Communicative language teaching in EFL university context: Challenges for teachers. Journal of Language Teaching and Research, 6 (5), 976-984.

[6] Basta, J. (2011). The role of the communicaticative approach and cooperative learning in higher education, Linguistic and Literature, $9(2), 125-143$.

[7] Caganaga, C.K. (2014). The effects of communicative approach on learners foreign language proficiency levels by using the needs analysis in english for specific purposes classes. International Online Journal of Education and Teaching (IOJET), 1 (2), 91-107.

[8] Chang, M. (2011). EFL Teachers' attitude toward communicative language teaching in Taiwanese. Asian EFL Journal Professional Teaching Articles, 53, 17-34.

[9] Chen, Y., Jiang, Y., \& Mu, Z. (2015). A survey study: The correlation between introversion/extroversion and oral english learning outcome. Journal of Language Teaching and Research, 6 (3), 581-587.

[10] Elmaksoud, M.A.E. (2013). The effect of using communicative approach on developing pronunciation sub-skills. Educational Research, 4 (3), 294-308.

[11] Harkio, N., \& Pietila, P. (2016). The role of vocabulary breadth and depth in reading comprehension: A quantitative study of finnish EFL learners. Journal of Language Teaching and Research, 7 (5), 1079-1088.

[12] Jafari, A.M., \& Rad, N.F. (2016). The influence of phonological and grammatical awawreness on EFL students' reading performance. Journal of Language Teaching and Research, 7 (5), 1164-1173.

[13] Jin, G. (2008). Application of communicative approach in college english teaching. Asian Social Science, 4 (4), 81-85.

[14] Jing, L., \& Minghe, G. (2015). The application of communicative approach in college oral english teaching. English Language Teaching, 2 (1), 35-39.

[15] Kasumi, H. (2015). Communicative language teaching and its impact on students' performance. Journal of Educational and Social Research, 5 (1), 155-162.

[16] Mesgharshahr, A., \& Abdollahzadeh, E. (2014). The impact of teaching communication strategies on EFL learners' willingness to communicate. Studies in Second Language Learning and Teaching, 4 (1), 51-76.

[17] Nurchasanah. 1995. Penerapan Pendekatan Komunikatif-Integratif dalam Interaksi Belajar Mengajar Bahasa Indonesia di Tingkat Dasar. Jurnal Bahasa, Sastra, Seni can Pengajarannya, 22 (1), 47-61.

[18] Sehe, Tolla, A., Kamaruddin, \& Hamsa, A. (2016). The development of Indonesian language learning materials based on local wisdom of the first grade students in SMA Negeri 3 Palopo. Journal of Language Teaching and Research, 7 (5), 913-922.

[19] Sekiziyivu, S., \& Mugimu, C.B. (2015). Retaionship between learners' german language communicative abilities and their prior performance in a national ugandan certificate examination. Journal of Language Teaching and Research, 6 (1), 45-52.

[20] Shahneaz, A., Amin, M., Sarker, A.K., Shahnaj, S., \& Mah,ud, B. (2013). The impact of communicative approach in developing english language skill in business education. Journal of Education and Practice, 5 (4), 143-149.

[21] Wiyono, B.B., \& Soetopo, H. (2015). Predictive validity of the English, Psychology, and Field of study competency tests towards graduate students' academic achievement. Journal of Basic and Applied Scientific Research, 9, 43-48.

[22] Wiyono, B.B. (2017). The effect of self-evaluation on the principals' transformational leadership, teamwork effectiveness, and school improvemen. International Journal of Leadership in Education, Theory and Practice, April, 1-21.

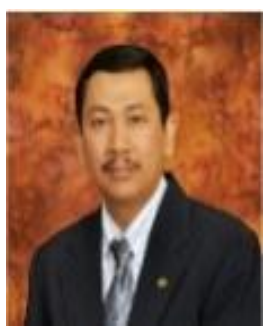

Bambang Budi Wiyono is a professor in education science. He is a Dean of Faculty of Education Universitas Negeri Malang Indonesia. He is an active researcher in field of education, include curriculum development, teaching and learning, educational evaluation, teacher development, educational management and leadership. He has conducted more than 40 researches in education. He has also authored many books in education, and has written several articles of journals on the topics. 


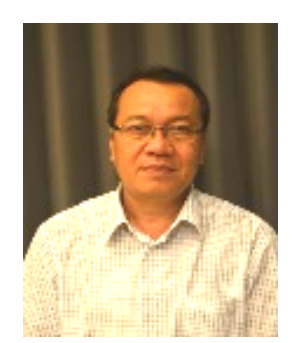

Muhana Gipayana is a doctor (associate professor) in Indonesian language education. He is a lecture in Department of Elementary School Teacher Education, Faculty of Education, Universitas Negeri Malang Indonesia. He is also an editor in chief of Elementary School Journal. He is an active researcher in field of basic education and linguistic. He has conducted many researches in education, include classroom action research, language education, curriculum development, linguistic, teaching and learning, and the others in basic education as well. In addition, he has authored many books in language education, and has written several articles of journals on the topics.

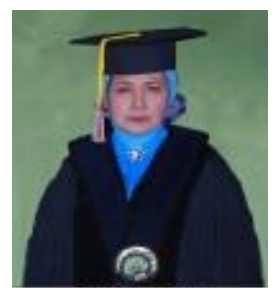

Ruminiati is a professor in educational sociology. She is a lecture in Department of Elementary School Teacher Education, Faculty of Education, Universitas Negeri Malang Indonesia. She is an active researcher in field of basic education. She has conducted many researches in education and sociology, include classroom action research, gender, special education, curriculum development, compulsory education, teaching and learning, and the others in basic education as well. In addition, she has authored and review many books in educational sociology. 